\title{
Leading the debate for the business case for gender equality, perilous for whom?
}

\author{
Pauline Cullen* (1) and Mary P. Murphy (1)
}

This research examines how the framing of the business case for gender equality (BCGE) in the European Union (EU) translates in the Irish national context and how different actors have engaged with this framing exercise. A central concern is how gender knowledge is mobilized by different actors as they compete to shape discourse, policy and practice on gender equality. We draw upon theoretical work that has interrogated the relationship between neoliberalism, gender inequality and feminist mobilization before reviewing critical assessments of the BCGE. The primary focus of this paper, having mapped this theoretical debate, is to analyse the role different Irish actors and organizations play in reproducing key frames and to examine the ambiguous or ambivalent engagement of different interest groups with this agenda. In turn, we assess the degree to which the agenda enables or disables structural change in access to power. We explore three case studies through which the BCGE in the EU was reinforced, adapted, resisted and rejected in our discussions, and draw out the constraints, opportunities and outcomes in each. Our first case study, which sets the national context for the following case studies, reviews how the Irish state interacts with the EU to frame gender equality and how it partners with key actors (state feminism and femocrats, private actors and feminist actors) to advance the BCGE. The second case study examines the role of the leading Irish feminist civil society organization (CSO) in the Women on Boards campaign that reinforces the dominant instrumental discourse associated with EU and national framing of gender parity on boards, and the ambiguity of feminists about this campaign. The third case study examines how Irish financial elites symbolically engage with gender parity on boards while simultaneously seeking to veto the implementation of gender representation targets proposed in the EU Capital Directive. It is clear that a degree of instrumentality informs most actors' framing of BCGE. We also find evidence of how power actors and financial elites, while rhetorically engaging in BCGE and employing it when relevant to develop reputational capital, will seek ultimately to protect the status quo rejecting the governance benefits implied in BCGE. Ultimately, our cases illustrate the potential of the BCGE to support the inclusion of women in governance structures yet demonstrate that engaging with BCGE is perilous for some.

Keywords: gender knowledge, feminism, business case for gender equality, neoliberalism

\section{Introduction}

$\mathrm{T}^{\mathrm{s}}$ his research examines how the framing of the business case for gender equality (BCGE) in the European Union (EU) translates in the Irish national context and how different actors have engaged with this framing exercise. A central concern is how gender knowledge is mobilized by different actors as they compete to shape discourse, policy and practice on gender equality. We draw upon theoretical work that has interrogated the relationship between neoliberalism, gender

Address for correspondence: *Pauline Cullen, Auxilia Building North Campus, Sociology, Maynooth University, National

University of Ireland, Maynooth, Co. Kildare, Ireland; e-mail: pauline.cullen@nuim.ie 
inequality and feminist mobilization (Fraser, 2013; McRobbie, 2009; Newman, 2013; Prügl, 2015; Rottenberg, 2014) before reviewing critical assessments of the BCGE (Elomaki, 2015a; Prügl \& True, 2014; Roberts, 2015). Following Prügl's (2015) advice to examine what is lost but also 'what is perhaps gained' (p. 615), we focus on literature that highlights the constraints and opportunities associated with engagement with marketized feminism (Kantola \& Squires, 2012) and how different actors in organizational contexts manipulate the paradoxes generated by neoliberalism (Ferree \& Zippel, 2015; Newman, 2013).

The primary focus of this paper, having mapped this theoretical debate, is to analyse the role different Irish actors and organizations play in reproducing key frames and to examine the ambiguous or ambivalent engagement of different interest groups with this agenda. In turn, we assess the degree to which the agenda enables or disables structural change in access to power (Prügl, 2015, p. 615). We explore three case studies through which the BCGE in the EU was reinforced, adapted, resisted and rejected in our discussions, and draw out the constraints, opportunities and outcomes in each. A central component of our analysis is the role of 'gender knowledge', understood here as forms of 'gender expertise' that are produced by women's organizations, public bodies, think tanks, corporate actors and international institutions. We proceed with an overview of key literature, outlining first the broad parameters of the key debate about neoliberalisms and feminisms. Next, following Elomaki (2015a), we examine five key themes that emerge from feminist interrogation of the BCGE and in turn analyse the role of the EU and capital interests in directing knowledge and initiatives on gender equality and corporate governance at the EU level. We then map our broad methodological approach. Our first case study, which also sets the national context for the following case studies, reviews how the Irish state interacts with the EU to frame gender equality and how it partners with key actors (state feminism and femocrats, private actors and feminist actors) to advance the BCGE. We do this by reviewing two examples of the state's active use of EU funding to promote an instrumental view of gender equality. The second and third case studies enable us to compare and contrast how organizations and actors adapt and reinterpret the framing of the BCGE. The second case study examines the role of the leading Irish feminist civil society organization (CSO) in the Women on Boards campaign which reinforces the dominant instrumental discourse associated with EU and national framing of gender parity on boards, and the ambiguity of feminists about this campaign. The third case study examines how Irish financial elites symbolically engage with gender parity on boards while simultaneously seeking to veto the implementation of gender representation targets proposed in the EU Capital Directive. Our conclusion engages with key questions engaged with throughout our analysis and addresses how different actors engage with gender knowledge.

\section{Neoliberalism and feminism}

Explorations of the relationship between neoliberalism and feminism have generated important insights into the constraints and opportunities that shape feminist efforts to challenge neoliberalism (Eschle \& Maiguashca, 2013; Newman, 2013; Walby, 2011). Neoliberalism is understood here as a complex and perpetually transforming process, project and ideology actualized in different ways in different contexts. This focus on the varied process of neoliberalization allows for an assessment of the various ways in which neoliberalisms and feminisms encounter one another (Prügl, 2015, p. 617). Prügl (2015, p. 617) identifies three understandings of neoliberalism: as a political project; economic ideology; and cultural formation. While these are not exclusive, these different meanings applied to neoliberalism map onto feminist critiques of contemporary feminism, namely, the co-optation of feminism into neoliberal economic projects; the integration of feminism into neoliberal ideology and the interweaving of feminist ideas and rationalities and technologies of neoliberal governmentality (Prügl, 2015, p. 617). The five key themes we identify within the BCGE (and discussed below) reflect elements of these theoretical distinctions (economic, political and cultural) and the associated feminist critiques of the neoliberalization of feminism, but first we unpack the three meanings of neoliberalism as they relate to feminism. 


\section{Feminism and neoliberal economic projects}

Scholars have mapped the appropriation of feminist politics by neoliberal economic projects and the ascendance of a form of neoliberal feminism that implicitly and explicitly supports neoliberal economic frameworks (Eisenstein, 2009; Fraser, 2009; McRobbie, 2009). Fraser (2009) warns that a lack of awareness among contemporary feminists that their struggles play out on the same field as struggles over the economy prevents them from seeing the unintended consequences of their claims and renders their claims available for resignification by neoliberal economic forces. The resultant 'splintering of the feminist critique' allows for the incorporation and partial recuperation of some strands by neoliberal capital interests (Fraser, 2009, p. 99). Roberts' (2015) analysis of transnational business feminism (TBF) adds complexity to this critique exploring international variations and coalitions of interest from public and private sectors including feminist organizations, capitalist states, international development organizations, non-governmental organizations (NGOs) and transnational corporations promoting female empowerment and gender equality. TBF rests on argumentation that investments made in women can (and should) be measured in terms of the cost savings to families and communities as well as in terms of boosting corporate profitability and national competitiveness. For Roberts (2016) this project facilitates a further entrenchment of the power of corporations to create 'expert' knowledge both about gender and about development. This model in turn draws on naturalized and essentialized views of women and gender relations that ignore the historical and structural causes of gender-based inequality.

\section{Feminism and ideological neoliberalization}

Prügl (2015, p. 618) identifies the ideological neoliberalization of feminism as specifically articulated through the TBF and the BCGE models. International economic institutions and large corporations, but also women's policy agencies and women's organizations, reproduce this ideology as they cast gender equality and women as social forces responsible for improving the market share of corporations and supporting national economic development (Elomaki, 2015a, p. 293). While providing arguments for gender equality, 'neoliberalized feminism retains an ideological commitment to rationalism, heteronormativity and genderless economic structures' (Prügl, 2015, p. 619). The BCGE exemplifies this ideological construct in its emphasis upon women's right to participate in the market economy as producers and consumers. The market is emptied of power relations and the monetary cost of gender oppression is quantified as are the gender dividends to be gained from this approach. Gender ideologies are employed that construct women as more risk averse than men with longerterm goals, understood as essential in redressing the male risk-taking behaviour that predominates in corporate and financial decision-making. This monolithic assessment leaves little room for considering how social constructions of masculinity and femininity and pressures to adhere to gender norms are rooted in hierarchies of power (Nelson, 2012, p. 24).

\section{Feminism and neoliberal governance}

The third aspect of neoliberalizing feminisms identified by Prügl (2015, p. 619) refers to the governance dimensions, involving an institutional change in the relationship between feminist movements and the state and the linking of gender ideologies with projects of responsibilization. In the context of New Public Management, this is exemplified in an increase in audit culture that has resulted in the emergence of a form of market feminism (Kantola \& Squires, 2012). Market feminism is connected to new forms and technologies of governance where the state contracts out to civil society and relies on transnationalized networks of gender experts that results in a professionalization of movement activists (Prügl, 2015, p. 620). Specifically, a reliance on evidence-based gender expertise in turn requires funding stability that has been linked to the redirecting of feminist goals (Fraser, 2013).

Neoliberal feminism as governance also works to further entrench neoliberalism by responsibilizing women and by producing individuated feminist subjects who define liberation as self-care and meld neoliberal rationality with emancipatory projects (Rottenberg, 2014). These forms 
of engagement are often directed to elite women and communicated as career advancement rather than projects for gender justice extended to all women (Folbre, 2017; Hozic \& True, 2016). From this perspective, neoliberal feminist discourses become a governing force that help to neutralize the potential critique from other strands of feminism:

No longer concerned with issues, such as the gendered wage gap, sexual harassment, rape or domestic violence, ambitious individual middle-class women themselves become both the problem and the solution in the neoliberal feminist age. (Rottenberg, 2014, p. 423)

Gender mainstreaming and diversity management play a specific role here as technologies that have helped adapt feminist ideas to neoliberal rationalities with uneven consequences.

In sum for Prügl (2015, p. 620) the neoliberalization of feminism involves the integration of gender equality into economic restructuring; the integration of feminism into neoliberal ideology supported by the associated changes in rationalities and technologies of governance. However, alongside this critique and assessment is the acknowledgement that despite the power and influence of neoliberal rationality, it also generates internal contradictions and incoherencies, which allow for an engagement rather than a blanket denouncement of neoliberal feminisms. Rottenberg (2014, p. 424) suggests identifying and working within the potential fault lines of this neoliberalizing project highlighting the gaping irreconcilability between the notion of true gender equality and the turn towards intricate processes of individuation. Other analyses support this call to critically engage with neoliberalism, arguing for a more nuanced notion of resistance and radicalism that builds shared projects generated through encounters between feminist and other activist claims (Eschle \& Maiguashca, 2013; Evans \& Chamberlain, 2015).

Newman (2013, p. 210) reminds us how while women's activism helped neoliberalism to adapt and flex, and work the spaces of power, it made new demands on capitalism (including those of equality, rights, welfare benefits and provision for 'care'). Recent research on the Irish case suggests the existence of effective situated feminist and gendered resistance to neoliberal austerity that produced successful resistance to austerity (Cullen \& Murphy, 2017). This is consistent with Prügl's (2015, p. 615) notion of 'potentially productive contradictions in spaces carved out for feminist politics'. Working from this perspective, we now turn to an empirical feminist interrogation of the BCGE as an exemplar of the varied and various projects neoliberalizing feminism.

\section{The feminist analysis of the BCGE}

In her analysis, Elomaki (2015a) sets out the insights generated from feminist analysis of the impact of neoliberalism on gender equality discourses, policies and feminism. In her overview, she assesses the purchase but also the critique of the BCGE (Elomaki, 2015a, pp. 293-4). Economic actors and international institutions (the World Bank and the EU) play a central role in selecting certain feminist ideas and combining these with elements of neoclassical economic theory. This is bolstered by the work of private corporations employing gender and diversity discourses and agendas through private-public partnerships (Prügl \& True, 2014) and the production of knowledge on women and gender relations (Roberts, 2015). According to Elomaki (2015a):

this connection works in two directions: claims to gender equality shape our understandings of the economy and support certain economic policies, and economic theories and policies embody certain understandings of gender and have impacts on gender equality. (p. 291)

This model at the same time perpetuates essentialized understandings of women and girls and naturalizes the role of corporations as contexts that create knowledge about women and gender that results in simplified and instrumentalist solutions where gender equality is reduced to a simple measurable and profitable goal (Roberts, 2015, p. 18). In methodological terms, Table 1 isolates five strands of sub-arguments characterizing the BCGE and indicators for each strand. These are: audit governance techniques; women as customers and employees; diversity predictability theory; 
Table 1: Feminist analysis of BCGE (Elomaki, 2015a, 2015b; Prügl E True, 2014; Roberts, 2015)

\begin{tabular}{|c|c|}
\hline Theme BCGE & Indicators BCGE \\
\hline \multirow[t]{3}{*}{ Audit and governance techniques } & Cost Benefit Analysis, Managerialism \\
\hline & $\begin{array}{l}\text { Investments in women measured in cost saving or profits to } \\
\text { families, communities, corporations or in terms of national } \\
\text { competitiveness }\end{array}$ \\
\hline & $\begin{array}{l}\text { Perceived neutrality of structural inequality/gender equality } \\
\text { reduced to simple measurable and profitable goal }\end{array}$ \\
\hline \multirow[t]{3}{*}{ Women as customers and employees } & Branding women in market terms \\
\hline & $\begin{array}{l}\text { Women less risk averse to act as brakes on male corporate } \\
\text { behaviour }\end{array}$ \\
\hline & $\begin{array}{l}\text { Ignores social construction of gender roles and market power } \\
\text { relations }\end{array}$ \\
\hline \multirow[t]{4}{*}{ Diversity prediction theorem } & Weaponize diversity as competitive strategy \\
\hline & Shift from gender equality to diversity \\
\hline & $\begin{array}{l}\text { Diverse boards create better corporate governance (no need for } \\
\text { public regulation) }\end{array}$ \\
\hline & Naturalized/essentialized gender constructs \\
\hline \multirow{4}{*}{ Governmentality } & Individual rational choice models \\
\hline & Career advancement rather than gender justice \\
\hline & Consistent with EU models \\
\hline & Obscure power/gender conflicts/structural factors \\
\hline \multirow{5}{*}{$\begin{array}{l}\text { Gender mainstreaming } \\
\text { Diversity management }\end{array}$} & Feminist engagement with managerial governance in \\
\hline & institutional contexts \\
\hline & Change 'culture' to create structural change \\
\hline & Change agents will 'let down the ladder not shut the door' \\
\hline & Critical engagement and critical non-engagement \\
\hline
\end{tabular}

governmentality; diversity management and gender mainstreaming. While presented here as a set of indicators we acknowledge these strands are not necessarily compatible, can be in tension with one another and or reinforce one another. These themes and indicators reflect the economic, ideological and cultural facets of neoliberalized feminism as identified by Prügl (2015) and discussed above. Later in the three case studies we test for the presence of these indicators.

A central theme within the BCGE are debates on the use of gender quotas to improve women's representation on corporate boards. Strong resistance from economic interests and an absence of party political support and or feminist campaigns are understood as the explanatory factors for poor levels of adoption and or compliance with corporate gender quotas (Agustin \& Siim, 2015). Analysis underlines how despite the use of or the 'threat' of legislative or mandatory gender quotas on public and private boards as a way of encouraging action, capital interests were remarkably creative in resisting or circumventing such initiatives in some contexts (Agustin \& Siim, 2015). Corporate gender quotas feature strongly in the BCGE at the EU level and reflect a shift from a rights-based gender equality discourse to the market-oriented economic case that privileges the role of capital interests (Elomaki, 2015a, p. 290).

\section{The EU framework on corporate boards and gender equality}

Elomaki (2015a) details the EU's construction of women's underrepresentation in economic decisionmaking as a policy problem in the form of an EU directive on boardroom quotas. The European Commission (EC) proposed an EU directive on gender balance on corporate boards in November 2012, setting a target of 40 per cent of the underrepresented sex for the non-executive boards of large publicly listed companies, to be achieved by 2020 . The proposal does not oblige member states to impose sanctions but, significantly, marks a legislative approach that had been lacking in EU gender 
equality. The directive is oriented towards the business benefits of board parity and ties national economic growth and competitiveness to gender equality.

Elomaki (2015a) observed a significant break between the origins of the EU's efforts to politicize and legislate on gender equality (in politics leaning on justice and democratic arguments) to, by 2010, and in part as a reaction to the economic crisis, a new debate about women in economic decision-making. The main drivers behind these developments were corporate actors (Credit Suisse Research Institute, McKinsey \& Company, Deutsche Bank, Ernst and Young) with feminist organizations and actors including the European Parliament coming to support these initiatives later on and in a more nuanced fashion (Elomaki, 2015b). In fact, the absence of feminist voices from the initial shaping of the policy problem is understood as an important factor behind the economization of the debate on gender equality and decision-making at EU level to privilege the issue of business leadership (Elomaki, 2015b, p. 13). The end result of this shift is that the gender equality problem of women's underrepresentation in decision-making positions has been replaced with the economic problem of the under-utilization of women's human capital' (Elomaki, 2015a, p. 13). From her perspective, the loss of a focus on democracy as an integral element of gender equality also made discursive politicization of the economy less possible and in turn gave room to an economizing of women's underrepresentation. These developments she contends are anchored around the proposed EU directive that employs the BCGE (Elomaki, (2015a), p. 295).

Following Prügl's (2015, p. 621) insistence on searching for progressive agendas, we see contradictions shaping the EU's adoption of the BCGE in the guise of corporate gender quotas. The Commission directive, is on the one hand aiming to regulate the business world in the name of gender equality, yet on the other it has brought the corporate language and its individualizing and depoliticizing tendencies into EU gender equality discourse (Elomaki 2015a). In this sense, policies that regulate the market and corporations in the name of gender equality may advance the neoliberal economization of public gender equality discourses and enhance corporate influence on them. Notably, the priorities of women's organizations are also shifting as gender issues which are compatible with the market agenda are prioritized. Movement building, legislation and redistributive practices to promote gender equality have also been partly replaced with a focus on changing attitudes, capacity building, incentives and normative standards (Elomaki, 2015b, p. 7). These processes in turn further obscure conflictual aspects of gendered power relations, the conflict between gender equality and market values, the failure to see women's political struggle as collective and to recognize its links to other struggles for social justice (Elomaki, 2015b, p. 7; Fraser, 2013). Crucially all this happens in the context of austerity and prioritization of fiscal stability - keeping public debt at bay and cutting public spending - that has been central to the EU's monetary policy and has led to cuts in public jobs, services and social spending. All measures that affect women disproportionately.

\section{Methodology}

Our methodological approach uses the indicators in Table 1 as a framework to offer empirical insights into feminist critiques of neoliberalism, specifically those that argue for assessing it as a more complex and differentiated phenomenon. We examine the empirical reality of how different actors and institutions, including women's organizations and feminist groups engage with, what are for many, strongly neoliberalist arguments supporting the BCGE. Following Newman (2013) and Prügl (2015), we also stress the ambivalent and/or conflicting forms of engagement and the mixed outcomes that arise from the resistance to and or support of the BCGE. In the first case study, we review how gender equality was framed in two state conferences funded by the EU. We briefly outline the key frames used and locate them in the core elements of the BCGE identified in the theory section confirming and problematizing the degree to which economic instrumentalism is the main frame. Greater adherence to the BCGE in the state-organized conferences were noted, perhaps influenced by a more direct relationship with EU frames and funding. We observe the absence of feminist organizations, which despite investing in this area of work and being in receipt of significant state resources to advance gender participation in women's decision-making, 
were not invited or involved as a contributor in either conference. In the second case study, a leading feminist national CSO utilizes state and EU funding to engage, in various ways, to promote women in decision-making under a 'Women on Boards' campaign banner. The controversial nature of this engagement were highlighted, the ambiguities of the actors involved and the degree to which the feminist organization reinforces instrumental frames that advance capital's interests, as well as searching for openings that enable progressive advancement. The third case study reviews the power of neoliberalized finance, through the actions of the Irish Directors Association (IDA) and the Irish Banking Federation (IBF) and their response to the implementation of the EU Capital Directive gender requirement on boards of financial institutions, highlighting effective resistance to and suppression of this Directive. In this regard, the requirement to improve gender representation is resisted, while a broader discourse of diversity at the expense of gender equality is embraced. To develop our case studies and engage with these questions we adopt a qualitative approach, combining interview data, participant observation and document analysis. This involved interviews with feminist actors, policymakers and public officials, and analysis of public, $\mathrm{CSO}$, and corporate and financial institutional documents at national and EU level. We also draw from our attendance at civil society and public/private-sponsored events on women in economic decision-making.

\section{Case study 1: talent, gender balance and leadership}

The first high-level conference, which took place in November 2014, was titled 'Investing in Talent, Promoting Gender Balanced Leadership' and was framed in a conceptual note prepared for the conference by the Gender Equality Division of the Department of Justice and Equality. ${ }^{1}$ This frame underscored the need to focus on the issue of gender-balanced leadership and drew on Organisation for Economic Co-operation and Development (OECD) and European research to demonstrate tangible and measurable benefits from better gender balance. These included: increased labour productivity; enhanced governance and performance; improved corporate image; higher return on investment; greater ability to attract and retain the best talent; increased workplace innovation; and a reduction in employee turnover. The explicit aim of the conference, funded by the EU Progress programme and organized with the assistance of the Irish employers' organization (Ibec), was to

bring senior personnel from both the public and the private sectors together to raise awareness of the economic and social benefits of gender balance in decision making, and to share knowledge and best practice of how we can proactively maximize the talent of our well educated women and support their career advancement into senior decision making roles to achieve gender balance in leadership positions.

This predominant economic frame, alongside the centrality of capital interests that included Dell, Citi, KPMG, Barclays Bank, BYN Mellon and Accenture as main contributors, demonstrate core elements of the BCGE. The WXN (Women's Executive Network) and the 30\% Club alongside experts from the Cranfield School of Management provided additional inputs. Contributions emphasized, 'that gender balance be defined in gender neutral terms, with a focus on talent and customers to avoid backlash against diversity initiatives'. Other inputs emphasized the role of data, metrics and indicators and the impact of diversity on brand value. A key panel in the event entitled, 'Winning the War for Talent, Empowering and Supporting Women Leaders' emphasized key strategies for career advancement alongside the need to emphasize gender balance and the bottom line.

Contributors also emphasized the purchasing power of women (70 per cent of consumer decisions are made by women in the EU) and the importance of a match between senior management and the consumer base. It was also argued that economic growth and sustained business investment require a diverse and highly skilled workforce. Human capital arguments were evident with the low numbers of women in senior decision-making positions in Ireland understood to represent a vast pool of 'untapped potential and underutilization of talent'. Notably, critiques of the market-oriented approach 
or broader assessments of the structural nature of gender inequality were eschewed in favour of what the conference report detailed as 'a positive event focusing on practical and successful measures for implementing change'. Notably, the EU representation at this event, a former Commission official, opened up possibilities, and offered one of the only dissenting voices in drawing attention to poor levels of adoption and compliance with gender quotas in the EU and the Irish context.

The second EU-funded conference, held in May 2015, was also a collaboration between Ibec and the state in the form of the Department of Justice, Equality and Law Reform. In the framing for 'Reversing the Paradox: Promoting Gender-Balanced Leadership' the tone was once again self-congratulatory and sought to avoid critique with the conference chairperson encouraging the conference 'to focus less on problems and more on possible solutions'. Contributing capital interests included CPL, Sodexo, Google, Intel, Pfizer, Dell, Institute of Directors and Mercer. The Minister for Justice (Mrs Frances Fitzgerald TD) evoked the waste of human capital in the gap between women in third level and senior management roles (the paradox). Overall the proceedings and inputs reflected little structural power analysis, rather progress was understood as achievable for individual women by removing barriers. This event also emphasized practical initiatives that corporations could employ to 'recognize talent, open the door to all and promote equal opportunities', the role of changing organizational culture and mind-sets was underlined as was supportive senior leadership. Childcare support, the equalization of domestic work and work-life balance for parents, not just for mothers, were highlighted by a minority of contributors. References to gender equality as a goal in its own right were present but overshadowed by arguments about utilizing the highly educated female workforce as necessary to reinforce and grow economic recovery. Various industry-led initiatives and women's business networks such as the 'The $30 \%$ Club' were showcased to illustrate ways of mainstreaming gender balance in order to increase competitiveness.

State representatives referenced, in statistical terms, the persistence of imbalances including board chairpersons, and the commitment in the Irish context to a 40 per cent target for state boards. In the state formulation, greater gender parity in decision-making was linked to the wider social and economic benefits of gender equality and the construction of the Irish state as a modern and inclusive $21^{\text {st }}$-century society. Capital interests (Mr Danny McCoy CEO Ibec) framed the lack of women in decision-making roles in a more instrumental fashion arguing

it is not a woman's or an ethical issue but a strategic issue - with women half the educated talent on the planet, half of the consumer and end users and with diversity key to unlocking innovation and driving growth.

From this perspective increasing the percentage of women on boards was key to enhancing economic performance, while narrowing the talent pool reduced competitive advantage.

In both events, despite efforts by some contributors to insert the issue of gender equality and or draw attention to broader issues of social reproduction, the BCGE frame predominated. The state's endorsement of the event, the use of EU funding and the prevalence ceded to economic elites and their forms of gender expertise combined to advance an unproblematized economic case for gender equality. The discursive effort made to frame the conference as an opportunity for positive thinking worked as a powerful device to silence critique of BCGE. The predominant feminist organization the National Women's Council of Ireland (NWCI), the focus of the next case study, attended both conferences but was not formally included in either event. In effect, the absence of a counterpoint in the form of a feminist assessment is a key feature of debates on the economic case for gender equality in the Irish context and highlights how limited the opportunity is to open up spaces or advance progressive agendas.

\section{Case study 2: The National Women's Council of Ireland (NWCI)}

The NWCI, established in 1973, has 180 affiliated member organizations comprised of women's groups, women's sections or committees of larger national organizations such as trade unions and political parties, and organizations where women comprise a majority of members. The NWCI represents the most institutionalized form of feminist mobilization, but has been recognized as unique in 
combining a broad representation of different groups and diversity in feminist claims with varying degrees of success (Cullen, 2008).

Economic arguments for gender equality have become an important element in the NWCI work programme, a function, in large part, of their relationship with the EU and their long-term receipt of EU funds. EU policy imperatives are visible in the trajectory of the organization and campaigns on the gender pay gap, violence against women (EU Daphne programme), and most recently initiatives on women in political and economic decision-making. The NWCI Strategic Plan (2013-2015) directly refers to EU policy:

A number of policies at European level underpin the goals outlined in this Strategic Plan - increase the economic participation of women, and to establish strategies to address economic independence, equal pay, the representation of women in decision-making and positions of power, respect for women's dignity and integrity and an end to gender-based violence. (NWCI, 2014, p. 7)

NWCI economic arguments for gender equality have also been influenced by the Brussels-based women's rights NGO the European Women's Lobby (EWL). Interviews with past directors and vice presidents of the NWCI confirm the EWL as an important strategic ally particularly in the late 1990s and early 2000s (Cullen, 2008). While this relationship has waxed and waned in the past decade, in recent times EWL work on economic decision-making has had purchase for the NWCI and in particular its focus on the EU Women on Boards Directive.

Notwithstanding the EWL attempts to maintain a gender equality frame on economic participation, the NWCI's strategic engagement with EU initiatives and the BCGE must be understood in the broader context of the gendered outcomes of austerity at EU and national level and the acceleration of a longerterm diminishment in the EU's commitment to gender equality (Rubery, 2015). In the Irish context austerity has had specific gendered consequences with a similar outcome in the decline of infrastructure and funding devoted to addressing gender inequality (Barry \& Conroy, 2014). This involved a significant contraction in state funds for gender equality programmes and organizations including a deep cut in funds for the NWCI and its constituent members (Murphy, 2015). Access to policy contexts had also diminished, for example, under the conditions of the International Monetary Fund/European Central Bank (IMF/ECB) bailout Ireland had not been required to contribute annual reports within the EU OMC processes including the Country Specific Recommendations (CSRs) and Structural Funds. This meant less opportunity for the NWCI to be consulted and no opportunity to provide feedback on gender mainstreaming (GM) across the economic indicators. Although reversed since Ireland exited the bailout in late 2013, the NWCI assessment of this form of input is that GM seemed quantifiably weaker at both national and EU level. From the NWCI director's perspective, overarching commitments at EU level 'don't seem to filter down at all into the CSRs'. In her view, the frameworks that had 'helped us in the 1990s, seemed very far away now'. When asked overall to assess the current context for gender equality at EU level, the director remarked on how little legislative activity existed outside of some non-binding proposals for improving women's position in economic decision-making.

Despite the weakening of gender equality as a goal at EU level the NWCI decided in 2014 to establish a European policy group amongst its membership. This was motivated by an attempt to save the time and effort spent influencing the agendas of other Irish chapters of EU-level groups, to avoid 'being pulled into other people's agendas' and to reflect on how best the organization could use the EU in strategic terms. Adept at securing past EU funding and eager to plug the gap left by reduced state funding, the NWCI seized on EU funding to pursue the Irish commitment to EU proposals on quota legislation for women on boards of public corporations. Interview data confirms that financial considerations were a key element in the NWCI decision to accept this support which in turn facilitated the employment of a policy officer dedicated to strengthening the organization's work in the area of women and leadership. Receipt of this EU and state support also marked a new phase for the organization, which had worked through a contentious period marked by the resignation of their former $\mathrm{CEO}$ as an act of protest to state cuts to their core budget. This resignation had involved a public rebuke of the then government department and Minister for Justice and Equality and the current CEO had worked for a number of years to repair relations and position the organization as a worthy and reliable recipient of state funds to support gender equality. ${ }^{2}$ In strategic terms, the 
NWCI was clear that the Irish business community, backed by the EU-level interest group Business Europe, maintained a strong opposition to any binding quotas. In this context, careful consideration was given by the NWCI to framing the debate on gender parity and business. As such the organization chose the well-known proponent of gender parity in decision-making Halla Tomasdottir (2011), co-founder of Sisters Capital, Iceland, to reflect on the Icelandic response to the banking crisis.

In March 2015, the NWCI launched its campaign 'Better Boards, Better Business, Better Society'3 with the stated aim of increasing the number of women on boards in Ireland. This report was orchestrated from a budget line at the NWCI devoted to women in leadership, supported in part by EU funds and the Irish Department of Justice and Equality. The report makes four recommendations to increase what the NWCI refer to as board diversity in Ireland, as well as testimonials from five senior female decision-makers with varying levels of gendered analysis, sharing their experiences on a variety of different Irish boards. While all support greater efforts to promote gender balance, none put forward a feminist assessment. The document also includes a detailed overview of the underrepresentation of women on Irish public and private boards and an assessment of the economic, business and societal arguments for redressing this imbalance, an account of the Irish state action and inaction on these issues, and a range of international examples of efforts to improve gender balance. Notably the handbook begins with a strong statement by the NWCI CEO that references sexism and discrimination as key factors in limiting women's access to senior decision-making roles. There is also an overview of gender segregation in the workforce, the gender pay gap and the role of unpaid care work in shaping women's access to senior roles. Up front the NWCI addresses critiques of their choice to campaign on this issue, stating

Given the broad set of challenges around women and work in Ireland - from unequal pay to unaffordable child care - why focus specifically on the boardroom? ... The current gender imbalance on Irish boards is a reflection of the systemic inequality in the workplace, as outlined above. But the board is also a highly visible place from which to affect change. Increasing the number of women on boards, therefore, should be based on both equality and economic grounds. (NWCI, 2015, p. 13)

The majority of the document then outlines the BCGE with recommendations aimed at different stakeholders in the public and private sector. These include supporting the pipeline, improving management, employing sanctions and monitoring for compliance. A variety of women in business initiatives nationally and internationally were showcased including the Irish $30 \%$ Club that 'promotes a business-led approach focused on developing a pipeline of senior female talent, and is opposed to mandatory quotas'. While these views are represented, the overall recommendations of the report include legislation for mandatory gender quotas. The document also includes a short section on the societal case for increased female representation in decision-making arguing male-dominated decision-making contributed to the poor policy outcomes associated with the economic crisis. Here the argumentation pivots between essentialized understandings of women's capacity to change the nature of decision-making and broader arguments for more diverse and democratic decision-making contexts. The societal case is also justified with reference to the role modelling effects of better female representation on gender stereotypes and bias reproduced through gender socialization as well as a call for a focus on unpaid care work and policy initiatives on parental and paternity leave. While the event and the visit were well received by NWCI members and the media it had little impact on the corporate or banking world constituencies.

The NWCI engagement with the BCGE also includes the February 2016 launch of a sample training pack, 'Recognizing and Challenging our Unconscious Bias', ${ }^{4}$ available to employers free of charge. The training pack, supported by state funds, provides tools for a half-day training workshop on unconscious gender bias. This instrument was developed with assistance from prominent female members of the business community and focuses on

the benefits to organizations of greater gender balance at middle and senior management levels, which include effective decision making and increased productivity... Taking a practical case-study style approach, participants are equipped with a greater understanding of unconscious bias and of how to 
identify and adapt their own workplace culture, processes and practice to promote gender balance. (NWCI, 2016, p. 2)

The organization now also participates in events including Inspire Fest, a corporate event aimed at increasing diversity in technology, science and the arts, and diversity-related conferences run by Accenture, $\mathrm{PwC}$ and other international corporations. Notably, as part of their efforts to grow the membership, the NWCI specifically targeted women's networks in corporations. Some of the newest members of the NWCI also include women's networking organizations such as Women in Technology and Science and Swan a network for women in high technology associated with the Symantec Corporation. However, the organization is aware of the tension that exists between a focus on growing membership and the broader goal of movement building or indeed organizational goals and feminist goals. There is a clear discomfort for some NWCI staff with the focus on attracting women from corporations seen by some as a pragmatic exercise in securing resources that threatens the core values of the organization. For those critical of the move, the inclusion of members from corporate contexts, may create asymmetries with less resource-rich members and exacerbate dynamics where some members have more capacity than others to influence the NWCI work programme. For others, this focus fits with the organization's stated aim of diversifying and representing all women in Ireland. This approach is defended by focusing on the benefits of supporting elite women in leadership roles to become change agents on a variety of issues. While the NWCI has embraced the business case it has also attenuated its call for women in decision-making beyond the boardroom. For example, seeking a political commitment to a 40 per cent gender balance on locally selected committees or boards involved in community development, alongside participatory budgeting and equality targets in local planning.

One clear finding in this case study is the degree to which the EU and feminist EU actors influenced a national feminist actor the NWCI. This influence must be understood in the context of a decline in tangible initiatives on gender equality at EU level and the reality that at national level the main source of funding for gender equality depends on EU monies now tied in significant ways to the BCGE agenda. While NWCI proactively engaged with wider frames they inevitably reinforced the BCGE in a variety of ways. Crisis is clearly relevant as context in that austerity cuts prompted the need to diversify funding sources. The NWCI also sought to create linkages between economic decisionmaking quotas at national and local levels. Although clearly aware of and engaging with gender knowledge and frameworks of capital interests, the NWCI 'Better Boards project' missed the opportunity to engage in the Irish Central Bank consultation on the gender governance target dimension of the EU Capital Requirement Directive, the focus of our third case study. Next, we return to Elomaki's (2015a) assessment of the internal contradictions that characterize the rise of the BCGE. In this case economic elites select elements of the BCGE that embrace diversity rather than gender and eschew forms of regulation including gender quotas.

\section{Case study 3: gender and corporate governance - the EU capital requirements directive}

Hozic and True (2016) argue that, despite the presence of the Lehman Sister hypotheses and narratives promoting BCGE in banking and finance institutions, a more gender-balanced financial sector is still elusive with financial institutions maintaining the core characteristics that fed into the financial crisis. Elson (2013) terms 'reductionist' arguments that more women in financial sector management would have avoided the crisis. Prügl (2016) argues we should be wary of narratives whereby inserting gender into discussions of the crisis enables a morality play or a narrative of 'fall, rise, and redemption through which finance capitalism is re-born both chastened and reformed' ( $\mathrm{p}$. 210). This, she argues, distracts from the structural relationship between finance and social reproduction where rising private debt and the financialization of everyday life happened in a context of securitization, AAA-rated collateralized debt obligations, unrealistic capital requirements of banks and the dearth of regulation (Prügl, 2015). 
The 'Lehman Sisters hypothesis' argues gender inequality in banking was a significant factor in the banking crisis and that more gender diversity in top finance would reduce behavioural drivers behind the crisis (Van Staveren, 2014). Analysis does support the idea that a virtual male monopoly on financial policy making produced gender-biased policies and a culture of groupthink that played into the financial crisis (Prügl, 2015). However, criticism of the link between such analysis and the BCGE, specifically the idea that a greater presence of women in financial governance is all that is required in its supposed capacity to automatically lead to greater transparency and better decisionmaking (Elomaki, 2015a). This said, feminist assessments of financial institutions and processes of financialization do include calls for greater gender representation in economic decision-making contexts. These assessments in their more critical form suggest the implementation of feminist economic approaches rather that the simple shift towards greater descriptive representation of women or the achievement of some form of critical mass (Chant \& Sweetman, 2012; Elson, 2013; Folbre, 2009).

Jonsdottir, Singh, Terjesen, and Vinnicombe (2015) emphasize how as part of the reaction to the banking crisis in Iceland, a focus on the gender composition has resulted in boards that are now either gender balanced or female dominated. Elson (2013) recounts how macho masculinity and male irresponsibility were identified as causes of the financial crisis in Iceland. Responses to the Icelandic crisis included the election of a new female Prime Minister, five female ministers of 11 in her cabinet, the elevation of two women to lead two failed nationalized banks and the input of a range of female investors working to reshape the financial sector. She also stresses the degree to which Iceland took control of and restructured banks, brought bankers to court, reregulated banks and restructured certain economic sectors, and that these reforms coincided with a reinvention of business and society that enhanced values of openness, fairness and social responsibility. In this way Prügl (2015) argues, rather than allowing finance to dominate the other spheres of the economy, finance was made to relate to, and service, production and reproduction.

In Ireland efforts to reform the financial system also included a 'paradigm shift' in macro and micro banking regulation and supervision that includes macro prudential policy tools including mortgage rules, countercyclical buffers and a strengthening of the mandate and capacity of key institutions including the Central Bank of Ireland (Clarke, 2017). Ireland also imposed stronger governance requirements for banks and credit institutions especially in relation to fitness, probity and directors' compliance. Rather than a 'comply or explain' regime these new corporate governance requirements were made statutory and considerable effort was invested in strengthening enforcement (Clarke, 2017, p. 115). Murphy (2014) however notes the absence of any Lehman's Sisters hypotheses in Ireland, where unlike Iceland, there has been little to no intervention aimed at changing board composition in gender terms.

In November 2014, four Irish banks were placed under the supervision of the new ECB Single Supervisory Mechanism (Bank of Ireland, Allied Irish Bank, Ulster Bank and Permanent TSB). At EU level, the issue of gender equality in banking and finance had been advanced. Michel Bariner, EU Internal Markets Commissioner, argued 'enhanced gender equality in banking governance is also an opportunity to address the group think that was a major factor behind the crisis affecting the global financial sector'.

As part of this agenda an EU Capital Requirements Directive (CRD 4) was introduced that engaged with gender quotas in banking governance processes (Spectrum, 2011, p. 8). This Directive concluded that diversity in board composition should contribute to effective risk oversight by boards, providing for a broader range of views and opinion. The CRD required high impact finance and banking institutions to employ a broad set of qualities and competences when recruiting members to the management body and to put in place a policy promoting diversity on the management body. Put simply, the CRD requires the nomination committees of significant institutions to decide on a target for the underrepresented gender on the board and to prepare a policy on how to increase the number of the underrepresented gender. Finally, institutions must make public their policy on diversity with regard to selection of members of the management body, its objectives and any relevant targets, and the extent to which these objectives and targets have been achieved. There is no gender equality prerogative, rather the logic follows the BCGE, with the stated aim of greater diversity to enhance governance. 
At the onset of the crisis, Irish banking governance was highly gendered and remains so with banking corporate governance representing perhaps the most highly gendered set of institutions (see Table 2). Gender was never a variable of analysis in any of the key political points of the Irish banking crisis including the events leading up to the September 2008 bank bailout; the numerous banking crisis reviews; and a parliamentary banking inquiry which reported in 2016. All of these reviews and inquiries were populated almost exclusively by all male committees and demonstrated little instrumental capacity to extricate any gendered learning from the governance failings associated with the banking crisis. This is evident in the response of Irish banks to the gender governance targets in the EU CRD. To implement the EU CRD in 2013 the Irish Central Bank initiated a Consultation on the Review of the Corporate Governance Code for Credit Institutions and Insurance Undertakings Consultation Paper CP 69 (Irish Central Bank, 2013, p. 13). It outlined key EU and EC policy and legal contexts and invited responses to Capital Requirements Directive IV requirement that 'significant' credit institutions establish a target for the representation of the underrepresented gender on the board and devise a policy to achieve the target. The Central Bank sought specific feedback from respondents as to whether a provision in relation to diversity requirements should be introduced into the Code and, if so, the nature of any such requirement. The Irish Banking Federation responded in September 2013 (IBF, 2013, p. 4) and argued 'we do not see merit in having any diversity provisions introduced into the Code that place an undue emphasis on gender diversity' (p. 13). Their full argument is worth quoting:

We acknowledge that diversity requirements (with particular reference to gender diversity) are being introduced under CRD IV. Gender diversity is only one component of board diversity which should consider a wide range of issues including, but not limited to, skill mix, regional and industry experience, background and gender. While a gender balance is desirable, the key concerns should be equal access for all, and appointment on the basis of merit ...

The Irish Institute of Directors (IOD) is another important capital interest group and in some respects a cheerleader for 'women on boards', commissioning research on the experience of women in boardrooms in 2013 and 2015 (IOD, 2015) and playing a role in both of the EU-funded conferences discussed earlier. However, in their 2013 response to the Central Bank consultation while confirming that diversity among directors is of paramount importance to the leadership and success of a business, echoing the sentiments of the IBF they commented:

however, the debate too often focuses on gender diversity, which is only one element, board diversity should encompass everything from the skills and expertise of directors, to their level of independence from the company, to their age, gender and nationality. $(I O D, 2013)$

Ireland transposed the CRD (2013/36/EU) into domestic law on 31 March 2014 by means of the EU (Capital Requirements) Regulations 2014 (S.I. 158/2014) ('CRD') and the four financial institutions designated as 'significant' are required to report under Regulation 64(5) of CRD. Regulation 84 of

Table 2: Gender representation in corporate governance of Irish banks

\begin{tabular}{|lccc|}
\hline Banks & $\mathbf{2 0 0 9}$ & $\mathbf{2 0 1 4}$ & $\mathbf{2 0 1 5}$ \\
\hline Allied Irish Bank & $2 / 11$ & $1 / 12$ & $2 / 10$ \\
Bank of Ireland & $1 / 9$ & $1 / 12$ & $2 / 12$ \\
Northern 2009-2013 & $0 / 10$ & $3 / 12$ & $3 / 12$ \\
Danske 2014-2016 & Ulster Bank & $1 / 8$ & $3 / 10$ \\
Permanent TSB & representatives) & $3 / 13$ & $2 / 7$ \\
\hline $\begin{array}{l}\text { Source. Murphy (2014) and 2014, 2015 Annual Reports of Allied Irish Bank, Bank of Ireland, Dankse, Ulster } \\
\text { and Permanent TSB. }\end{array}$ & & \\
\hline
\end{tabular}


CRD requires institutions to explain, on their website, how they comply with the requirements of Regulations 76-83 of the CRD, which relate primarily to Governance, Remuneration and Reporting. The Irish Central Bank imposition of this corporate governance code contains no reference to any target for gender equality on banking governance and the Irish Central Bank has not imposed the gender reporting requirement. Rather section 14.10 of the code advises the

The board shall put in place a formal skills matrix to ensure that there is an appropriate skills mix across members of the board and potential new members should be assessed against the skills matrix during the appointment process.

Banks have varied in their reporting responses. Ulster Bank, a major financial player in the Irish context (2016), was able to adopt a minimal reporting that:

the Board is structured to ensure that the directors provide UBIL with the appropriate balance of skills, experience and knowledge as well as independence.

Allied Irish Bank, another major Irish financial institution (2016), took a wider approach reporting

... in response to CRD Regulation 76(4)(iv), the Board approved a Board Diversity Policy during February 2015 which states that the Board's aim, with regard to gender diversity, is to ensure that the percentage of females on the Board reaches or exceeds 25 per cent by the end of 2016 and thereafter ... the Committee is satisfied that adequate progress is being made in addressing the underrepresentation of female members on the Board, with the percentage of females on the Board currently at 20\%. The Board Diversity Policy is available on AIB's website.

As Table 2 suggests, change is slow, with some limited improvement in the gender composition of Irish banking boards. However, all female members of Irish banking boards are non-executive roles suggesting, regardless of gender targets, there has been little progress in redressing the clear structural gender imbalance in senior executive teams or growing the internal executive pipeline (Ahern \& Clarke, 2013).

A number of conclusions can be drawn from this case study. EU framing of policy in relation to gendered issues in corporate finance governance is visible in discursive terms in the Irish context, specifically in support for a diversity rather than gender parity paradigm. There is also collaboration between finance institutions in lobbying and collaboration and between business schools and women's business networks including the $30 \% \mathrm{Club}$, in the production and framing of knowledge concerning gender participation in banking governance. We also see successful lobbying against gender reporting on gender targets in banking governance, in spite of formal commitments of bodies including the IOD and their participation in various EU-funded conferences promoting gender participation on boards. In effect, the Irish case mirrors the narrow BCGE frameworks deployed by state and capital interests and the lack of institutional support for and forms of resistance to economic gender quotas that were found in other EU countries (Agustin \& Siim, 2015). Despite clear engagement on the wider issues concerning women on boards there has been no clear feminist critique from the NWCI, femocrats or others, in the Central Bank consultation on the CRD.

Table 3: Indicators present across conferences, NWCI, CRD case studies

\begin{tabular}{|lcccccc|}
\hline Case studies & $\begin{array}{c}\text { Audit/ } \\
\text { NPM }\end{array}$ & $\begin{array}{c}\text { Customer/ } \\
\text { employee }\end{array}$ & $\begin{array}{c}\text { Diversity } \\
\text { Prediction Theorem }\end{array}$ & Governmentality & Diversity & $\begin{array}{c}\text { EU } \\
\text { BCGE }\end{array}$ \\
\hline Conferences & $\mathrm{X}$ & $\mathrm{X}$ & $\mathrm{X}$ & $\mathrm{X}$ & $\mathrm{X}$ & $\mathrm{X}$ \\
NWCI & $\mathrm{X}$ & $\mathrm{X}$ & $\mathrm{X}$ & $\mathrm{X}$ & $\begin{array}{c}\mathrm{X} \\
\mathrm{X}\end{array}$ \\
Banks CRD & & & & & \\
\hline \multicolumn{7}{l}{ Source. Compiled by authors using case study data. } \\
\hline
\end{tabular}




\section{Conclusion}

In this analysis, we have presented three case studies that illustrate the BCGE. Prügl's (2015) classification of neoliberalism in its economic, ideological and cultural forms and associated feminist critiques of the co-optation of feminism into neoliberal economic projects; the integration of feminism into neoliberal ideology and the interweaving of feminist ideas and rationalities and technologies of neoliberal governmentality are all evident across our cases. Social forces contesting these processes and creating alternative discourses appear weak, as the BCGE proliferates in public and private institutions. The co-optation of feminist organizations into neoliberal projects is evident if incomplete as feminist actors work to nuance the totalizing discourse of the BCGE while aware of their participation in forms of governmentality and managerial governance. The marginalization of feminist actors from BCGE contexts particularly in the banking and financial context speaks to a continuity in terms of the power and intransigence of capital interests to progressive feminist justice claims. What is evident is in the contest over gender knowledge and expertise, movements are incorporated or replaced with expert networks that risk redefining and instrumentalizing the goals of gender equality (Prügl, 2015, p. 627). In this way, the integration of feminist ideas into discourses and practices of state, corporate and financial elites aligns with the broader economic, political and cultural projects of neoliberalism. However, the persistence of a focus on gender equality amidst the predominance of corporatized gender expertise indicates that the outcomes of the neoliberalization of feminism are not univocal (Prügl, 2015, p. 627). The NWCI, in working the spaces of power, have opened up new opportunities, have made creative use of funding and have developed expertise that they have used to subsequently critically reflect on and critique BCGE.

It is clear that a degree of superficial instrumentality lies behind actors' framing of the economic case for gender equality including state and economic elites. While we find evidence of discomfort with BCGE from feminist actors, and examples of feminist organizations and individual actors working to open up spaces of power and advance progressive agendas, we in turn find stronger evidence of Fraser's (2013) analysis of complicity alongside the power of capital interests to subvert and co-opt knowledge and political space around gender equality. Our review of the two conferences devoted to advocating the BCGE in Ireland showed a high degree of overlap with the core themes or indicators that characterize the BCGE (Tables 1 and 3). Economic argumentation, essentialized gender ideologies and constructs were tied to discourses of responsibilization and the power of governance technologies and rationalities of gender and diversity management to deliver economic benefits to women and men, corporations and society writ large.

The role of international corporations in framing knowledge production processes at the national level was also particularly evident. Yet we noted the continued existence of a gender equality frame, alongside some ambivalences and contestations. It was EU officials presenting at the national conferences who were critical of capital interests and drew attention to the poor levels of support across different countries for binding legislation on gender quotas. Finally, we observe the absence of the national feminist representative organization the NWCI who, despite investing in this area of work and being in receipt of state resources to advance gender participation in women's decision-making, were not involved as an actor in either national conference, nor engaged with the CRD-related lobbying. From this perspective, while our second case study illustrates efforts to discursively reframe the most instrumental and economistic elements of the BCGE, feminist actors remain a side show with little traction in national policy debates or influence over the actions of private interests. They have subsequently reflected on how to critically engage as feminists in this field. The example of the CRD reminds us however of how power actors and financial elites, while rhetorically engaging in BCGE, and employing it when relevant to develop reputational capital, will seek ultimately to protect the status quo rejecting the governance benefits implied in BCGE. Ultimately, our cases illustrate the potential of the BCGE to support the inclusion of women in governance structures yet demonstrate that engaging with BCGE is perilous for some. 


\section{Declaration of conflicting interest}

The authors declared no potential conflicts of interest with respect to the authorship and/or publication of this article.

\section{Endnotes}

1. All references to data can be found in the concept note in the conference brochure here, references for conference publications are in the references. http://www.genderequality.ie/en/GE/Final\% 20Conference\%20Programme-Interactive.pdf/Files/Final\%20Conference\%20Programme-Interactive.pdf and http://www.genderequality.ie/en/GE/Conference $\% 20$ Report $\% 20-\% 20$ Reversing $\%$ 20the $\% 20$ Paradox.pdf/Files/Conference $\% 20$ Report $\% 20-\% 20$ Reversing $\% 20$ the $\% 20$ Paradox.pdf

2. Interview with the CEO of the NWCI, May 2015.

3. http://www.nwci.ie/index.php?/learn/publication/better_boards_better_business_better_ society\#sthash.CrJnjnhj.dpuf

4. http://www.nwci.ie/index.php?/learn/article/recognising_and_challenging_our_unconscious_ bias\#sthash.8VzgqoN4.dpuf

\section{References}

Agustin, R. L., \& Siim, B. (Eds.). (2015). Dilemmas in the Danish approach to gender equality: Gender equality without gender quota (EUI Working Papers No. 27, Vol. 2015). Florence, Italy: European University Institute.

Ahern, D., \& Clarke, B. (2013, June). Listed companies' engagement with diversity: A multi-jurisdictional study of annual report disclosures. Dublin, Ireland: DJEI.

Barry, U., \& Conroy, P. (2014). Ireland in crisis 2008-2012: Women, austerity and inequality. In J. Rubery \& M. Karamessini (Eds.), Women and austerity - The economic crisis and the future for gender equality. London, UK: Routledge.

Central Bank of Ireland. (2015). Corporate governance requirements for credit institutions 2015. Dublin, Ireland: CBI.

Chant, S., \& Sweetman, C. (2012). Fixing women or fixing the world? 'Smart economics', efficiency approaches, and gender equality in development. Gender $\mathcal{E}$ Development, 20, 517-29.

Clarke, B. (2017). Banking regulation. In W. Roche, P. J. O'Connell, \& A. Prothero (Eds.), Austerity and recovery in Ireland (pp. 107-23). Oxford, UK: Oxford University Press.

Cullen, P. (2008). Irish women's organizations in an enlarged Europe. In S. Roth (Ed.), Gender issues and women's movements in the expanding European Union. Oslo, Norway: Berghahn Press.

Cullen, P., \& Murphy, M. P. (2014). Investing in talent: Promoting gender balanced leadership. Report of the Ibec and Department of Justice and Equality Conference.

Cullen, P., \& Murphy, M. P. (2015). Reversing the paradox: Promoting gender balanced leadership. Report of the Ibec and Department of Justice and Equality Conference.

Cullen, P., \& Murphy, M. P. (2017). Gendered mobilizations against austerity in Ireland. Gender, Work and Organization, 24, 83-97.

Eisenstein, H. (2009). Feminism seduced: How global elites use women's labor and ideas to exploit the world. Boulder, CO: Paradigm.

Elomaki, A. (2015a). The economic case for gender equality in the European Union: Selling gender equality to decision-makers and neoliberalism to women's organizations. European Journal of Women's Studies, 22, $288-302$.

Elomaki, A. (2015b). The ambivalent neoliberalism of the EU directive on gender balance on corporate boards Paper presented in the 4th European Conference on Politics \& Gender 11-13.6.2015

Elson, D. (2013). Economic crises from the 1980s to the 2010s. In S. M. Rai \& G. Waylen (Eds.), New frontiers in feminist political economy. London, UK: Routledge.

Eschle, C., \& Maiguashca, B. (2013). Reclaiming feminist futures: Co-opted and progressive politics in a neoliberal age. Political Studies, 62, 3, 634-51.

Evans, E \& Chamberlain, P. (2015). Critical waves: Exploring feminist identity, discourse and praxis in Western Feminism. Social Movement Studies 14, 4, 396-409.

Ferree, M. M., \& Kathrin, Z. (2015). Gender equality in the age of academic capitalism: Cassandra and Pollyanna Interpret University restructuring. Social Politics: International Studies in Gender, State, and Society, 22, 4, 561-84.

Folbre, N. (2009). Greed, lust and gender: A history of economic ideas. Oxford, UK: Oxford University Press.

Folbre, N. (2017). The feminist business in Short takes: Feminist provocations on public feminism. Signs: Journal of Women in Culture and Society. Retrieved from http:/ / signsjournal.org/unfinished-business/

Fraser, N. (2009). Feminism, capitalism and the cunning of history. New Left Review, 56, 97-117.

Fraser, N. (2013). Fortunes of feminism: From state-managed capitalism to neoliberal crisis. New York, NY: Verso Books.

Hozic, A., \& True, J. (2016). Making feminist sense of the global financial crisis. In A. Hozic \& J. True (Eds.), Scandalous economics: Gender and the politics of financial crises (pp. 3-21). Oxford, UK: Oxford University Press. 
Institute of Directors (IOD). (2013). Response to consultation on the review of the Corporate Governance Code for Credit Institutions and Insurance Undertakings. Dublin, Ireland: Author.

Institute of Directors (IOD). (2015). Women on boards in Ireland 2015. Dublin, Ireland: Author.

Irish Banking Federation (IBF). (2013). Response to Central Bank consultation on board diversity (Section 7). Dublin, Ireland: Author.

Irish Central Bank. (2013). Consultation on the review of the Corporate Governance Code for Credit Institutions and Insurance Undertakings Consultation Paper (CP 69). Dublin, Ireland: Author.

Jonsdottir, T., Singh, V., Terjesen, S., \& Vinnicombe, S. (2015). Director identity in pre- and post-crisis Iceland: Effects of board life stage and gender. Gender in Management: An International Journal, 30, 572-94.

Kantola, J., \& Squires, J. (2012). From state feminism to market feminism? International Political Science Review, 33, $382-400$

McRobbie, A. (2009). The aftermath of feminism: Gender, culture and social change. London, UK: Sage.

Murphy, M. (2014). Ireland: Celtic tiger in austerity — Explaining Irish path dependency. Journal of Contemporary European Studies, 22, 132-42.

Murphy, M. P. (2015). Gendering the narrative of the Irish crisis. Irish Political Studies, 30, 120.

Nelson, J. A. (2012). Are women really more risk-averse than men?. INET Research Note \#012

Newman, J. (2013). Spaces of power: Feminism, neoliberalism and gendered labor. Social Politics, 20, $200-21$.

NWCI. (2015). Better boards, better business, and better society: A handbook for increasing women on boards in Ireland. Retrieved from http://www.nwci.ie/images/uploads/Better_Boards_PDF.pdf

NWCI. (2016). Recognising and challenging our unconscious bias training pack. Retrieved from http://www. nwci.ie/images/uploads/NWCI_Training_Pack_Final.pdf

Prügl, E. (2012). 'If Lehman Brothers had been Lehman Sisters ...': Gender and myth in the aftermath of the financial crisis. International Political Sociology, 6, 21-35.

Prügl, E. (2015). Neoliberalising feminism. New Political Economy, 20, 614-31.

Prügl, E. (2016). 'Lehman brothers and sister': revisiting gender and myth five years after the financial crisis. In Hozic, A. A. and True, J. (eds) Scandalous Economics: Gender and the Politics of Financial Crises, eds. Oxford University Press.

Prügl, E., \& True, J. (2014). Equality means business: Governing gender through public-private partnerships. Review of International Political Economy, 21, 1137-67. https://doi.org/10.1080/09692290.2013.849277

Roberts, A. (2015). Gender, financial deepening and the production of embodied finance: Towards a critical feminist analysis. Global Society, 29, 107-27.

Roberts, A. (2016). The limitations of transnational business feminism: The case of gender lens investing. Soundings, 62, 68-83.

Rottenberg, C. (2014). The rise of neoliberal feminism. Cultural Studies, 28, 418-37. https://doi.org/10.1080/ 09502386.2013 .857361

Rubery, J. (2015). Austerity and the future for gender equality in Europe. Industrial and Labor Relations Review, 68, $715-41$.

Spectrum. (2011, December). Irish Banking Officials Association Spectrum. Retrieved from www.iboa.ie

Tomasdottir, H. (2011, December). A feminine response to Iceland's financial crash. Retrieved from http:/ /www. ted.com/talks/halla_tomasdottir.html

Van Staveren, I. (2014). Lehman Sisters hypothesis. Cambridge Journal of Economics, 38, 995-1014. https://doi.org/ 10.1093 /cje/beu010

Walby, S. (2011). The future of feminism. Cambridge, UK: Polity Press.

\section{Biographical notes}

Pauline Cullen lecturers in Sociology and Politics in the Department of Sociology, Maynooth University, National University of Ireland. Her work examines civil society mobilization on social justice and gender equality at national and EU level, women's movements and gender and political representation. Her work has been published in the Journal of Civil Society, Social Movement Studies and Gender, Work and Organization.

Mary P. Murphy lectures in Irish Politics and Society in the Department of Sociology, Maynooth University. She has research interests in gender and social security, globalization and welfare states, activation, the politics of redistribution, and power and civil society. Recent publications include Careless to Careful Activation: Making Activation Work for Women (Dublin: NWCI, 2012) and (co-edited with Fiona Dukelow) The Irish Welfare State in the 21 Century Challenges and Changes (Basingstoke: Palgrave, 2016). An active advocate for social justice and equality, she is a part-time Commissioner on the Irish Human Rights and Equality Commission. 